\title{
Revisiting Indonesian public reactions against Danish cartoons depicting prophet Muhammad $^{1}$
}

\author{
Al Makin \\ Sunan Kalijaga State Islamic University and Indonesian Consortium for Religious \\ Studies, Yogyakarta \\ E-mail:almakin3@gmail.com
}

DOI: $10.18326 /$ ijims.v5i2.195-229

\begin{abstract}
This paper revisits the case of cartoon controversy in 2006, particularly focusing on the way in which the Indonesian public reacted against the twelve Muhammad Danish cartoons by the Jylands-Posten published in September 30, 2005. The study remains relevant as the case reflects not only Muslims' reaction against the blasphemy theologically but it also mirrors the new face of Indonesian Islam in the reform era which has given birth to a new free public

${ }^{1}$ The draft of this paper was presented at the International Consortium for Research in the Humanities, field research four: Religion and Globalization, Dynamic in the History of Religions between Asia and Europe, Ruhr University Bochum, September 8, 2009. My thanks should go to Ilham Khoiri (Kompas), Asrori S. Karni (Gatra), and Alimin Muchtar who helped me trace sources. I would also like to express my gratitude to Prof. Marion Eggert (Ruhr University Bochum), Prof. Stefan Reichmuth (Ruhr University Bochum), Prof. Timothy Daniels (Hofstra University), and Prof. Amy Remensnyder (Brown University) for their valuable advises. I then revised this work during my fellowship at the Asia Research Institute (ARI), National University of Singapore (NUS), in February 2012. On January 2014, the Ministry of Religious Affairs of Indonesia granted me an opportunity to visit Heidelberg University, where I revised again this paper. For the Ministry's grant I thank Prof. Dede Rosyada, Prof. Amin Abdullah, Prof. Faisal Ismail, and Drs. Khoeroni.
\end{abstract}


space in which new differing ideologies emerged and were propagated in various media. This study particularly focuses on the selected thirteen op-ed pieces and one interview published by the Indonesian online media in January 2006three pieces published by Hidayatullah, one posted in a personal website, two published by Kompas, two by The Jakarta Post, one by Gatra, three by Tempo, one op-ed and one interview by JIL (Islamic Liberal Network). My analysis of these works reveals two groups with different arguments: radical and conservative return to their theological foundation to retaliate the cartoonists who committed blasphemy against their prophet, whereas liberals and progressive Indonesians rely on reasoning and draw cultural values in expressing their appraisals of the vilifying images.

Makalah ini berusaha mengkaji kembali kasus kontroversi kartun pada tahun 2006, terutama berfokus pada cara di mana masyarakat Indonesia bereaksi terhadap dua belas kartun Muhammad yang diterbitkan oleh surat kabar Denmark Jylands-Posten pada tanggal 30 September 2005. Studi ini tetap relevan sebagai kasus yang mencerminkan tidak hanya reaksi umat Islam terhadap penghujatan secara teologis tetapi juga mencerminkan wajah baru Islam Indonesia di era reformasi yang telah melahirkan ruang publik bebas baru di mana berbagai ideologi baru muncul dan disebarkan di berbagai media. Penelitian ini terutama fokus pada tiga belas buah edisi opini dan satu wawancara yang diterbitkan oleh media online Indonesia pada Januari 2006, yang terdiri dari tiga potong yang diterbitkan oleh Hidayatullah, yang diposting di sebuah situs pribadi, dua diterbitkan oleh Kompas, dua oleh The Jakarta Post, satu oleh Gatra, tiga Tempo, satu op-ed dan satu wawancara dengan JIL (Jaringan Islam Liberal). Analisis atas karya-karya ini mengungkapkan dua kelompok dengan argumen yang berbeda: kelompok radikal dan konservatif berpedoman pada landasan teologis mereka untuk membalas kartunis yang melakukan penghujatan terhadap nabi mereka, sedangkan kaum liberal dan progresif Indonesia mengandalkan penalaran dan menarik nilai-nilai budaya dalam mengekspresikan penilaian mereka atas gambar-gambar tersebut.

Keywords: Danish Cartoon; Indonesian Islam; Public reaction; Theology; Cultural Argument 


\section{Introduction}

The publication of the twelve Muhammad Danish cartoon on September 30, 2005 has drawn world's attention and sparked reactions particularly from the Muslims countries. The story goes that the cartoons controversy was initially limited to a national level, which the Danish government failed to cope with, but it then escalated into a global crisis ${ }^{2}$. Various protests against the cartoons publication led to violent riots in many Muslim majority states across Africa, Middle East, South and Southeast $\mathrm{Asia}^{3}$. The media certainly played a vital role in exacerbating Muslims' anger-who deem the status of Muhammad in high regard but failed to understand the Danish and European culture and context-with Denmark, where the cartoons were drawn and published for the first time ${ }^{4}$. Indeed, due to sensational news of the cartoons, local level and international media were eager to blow up the news, and often to exaggerate the case. This was one of the contributing factors yielding a long global crisis. The economic loss due to the boycott against the Danish products in the Middle Eastern countries did not end until 2007. Note, for example, that the Danish Arla foods employed various communication strategies to regain the trust from its Muslim consumers. ${ }^{5}$ In June 2008, still under

\footnotetext{
${ }^{2}$ Kristina Lindholm and Eva-Karin Olsson, "Crisis Communication as a Multilevel Game: The Muhammad Cartoons from a Crisis Diplomacy Perspective," The International Journal of Press/Politics 16, no. 2 (2011), 254-71; Anders Linde-Laursen, "Is Something Rotten in the State of Denmark? The Muhammad Cartoons and Danish Political Culture," Cont Islam Contemporary Islam/: Dynamics of Muslim Life 1, no. 3 (2007), 265-74; Marion G Muller, Esra Ozcan, and Ognyan Seizov, "Dangerous Depictions: A Visual Case Study of Contemporary Cartoon Controversies," Popular Communication 7, no. 1 (2009), 37.

${ }^{3}$ Ron E Hassner, "Blasphemy and Violence," ISQU International Studies Quarterly 55, no. 1 (2011), 23-45.

${ }^{4}$ A. J Hussain, "The Media's Role in a Clash of Misconceptions: The Case of the Danish Muhammad Cartoons," The Harvard International Journal of Press/Politics 12, no. 4 (2007), 112-30.

${ }^{5}$ John G Knight, Bradley S Mitchell, and Hongzhi Gao, "Riding out the Muhammad Cartoons Crisis: Contrasting Strategies and Outcomes," LRP Long Range Planning 42, no. 1
} 
the shadow of cartoons irritation, a mob attacked the Danish embassy in Pakistan, with six people being killed. ${ }^{6}$

All in all, the twelve Danish Muhammad cartoons harbour not only blatant mockery and blasphemous elements but also certain elements of 'liquid racism'.? It is therefore unsurprising that the impact of the twelve Danish cartoons upon Muslims' religious feeling was indeed devastating. ${ }^{8}$ On the other hand, in this complex plural globalized society, a certain level of 'harm' in communication, which often caused 'instability,' was often unavoidable. The cartoons controversy is a good illustration. ${ }^{9}$ Saunders, ${ }^{10}$ in this regard, highlights that Muslims' harsh reaction against the cartoons was part of defence mechanism of their identity as a globalized ummah (Islamic community), through which solidarity among them

(2009): 10; T. Kenn Gaither and Patricia A. Curtin, "Examining the Heuristic Value of Models of International Public Relations Practices: A Case Study of the Arla Foods Crisis," Journal of Public Relations Research 20 (2008), 115-37.

${ }^{6}$ David Keane, "Cartoon Violence and Freedom of Expression," Human Rights Quarterly, 304 (2008), 846.

7 "Interview with German Islam Expert Bassam Tibi: 'Europeans Have Stopped Defending Their Values," Spiegel Online, October 2, 2006, sec. International, http:// www.spiegel.de/international/spiegel/interview-with-german-islam-expert-bassam-tibieuropeans-have-stopped-defending-their-values-a-440340.html; Sune Laegaard, "Normative Interpreations of Diversity: The Muhammad Cartoons Controversy and the Importance of Context," Ethnicities 9, no. 3 (2009), 321-323; Keane, "Cartoon Violence and Freedom of Expression"..., 865.

${ }^{8}$ In fact, the cartoon itself in general "is at base an aggressive medium, an offensive weapon whose effect can be devastating." John Geipel, The Cartoon, A Short History of Graphic Comedy and Satire, London: David \& Charles, 1972, 21; Satirical and mocking pictures, in which certain parts of human body are exaggerated, can be found as early as in the Egyptian and Greece cultures Thomas Wright, History of Caricature EF Grotesque in Literature and Art: With Illustrations from Various Sources, Drawn and Engraved London: 1865), 1-22; Keane, "Cartoon Violence and Freedom of Expression"..., 848.

${ }^{9}$ Lars Tønder, "Freedom of Expression in an Age of Cartoon Wars," Theory Contemporary Political Theory 10, no. 2 (2011), 255-72.

${ }^{10}$ Robert A Saunders, "The Ummah as Nation: A Reappraisal in the Wake of the 'Cartoons Affair," Nations and Nationalism/ : Journal of the Association for the Study of Ethnicity and Nationalism 14, no. 2 (2008), 3030-3321. 
was built, particularly with fast cyberspace media. ${ }^{11}$ In the context of globalized world, Olesen ${ }^{12}$ argues that the publication of the cartoons and the reaction against it were part of transnational dialectic process in which many nations with their own mission, agenda, and interests-either in defence of or objection to the publication of the cartoons-interacted. Indeed, the twelve cartoons were not mere mocking images. ${ }^{13}$ But, they have become public properties related to much more complex global communication among people with diverse cultures and various standards of morality.

It is true that the cartoons were drawn by the Danish artists and published in the country within the European context where the integration of Muslim immigrants and the project of pluralism became heated political issues in the public domain. ${ }^{14}$ However, the controversy which spread across the globe was unpredictable. Each country with its specific political, religious, and economic situation showed its own way to react. ${ }^{15} \mathrm{It}$ is,

${ }^{11}$ See Dale F. Eickelman and John W. Anderson, "Redefining Muslim Publics," in New Media in the Muslim World: The Emerging Public Sphere, Bloomington: Indiana University Press, 2003; For more studies on Indonesian public sphere see Robert W. Hefner, "Civic Pluralism Denied? The New Media and Jihadi Violence in Indonesia," in New Media in the Muslim World: The Emerging Public Sphere, ed. Dale F. Eickelman and John W. Anderson, Bloomington: Indiana University Press, 2003; Al Makin, "Benedict XVI and Islam: Indonesian Public Reactions to the Regensburg Address," Islam and Christian-Muslim Relations 20, no. 4 (2009), 409-21; Yasmin Ibrahim, "The Mediated 'Ummah' in Europe: The Islamic Audience in the Digital Age," in Media in the Enlarged Europe, Politics, Policy and Industry, ed. Alec Charles, Chicago: The University of Chichago Press, 2009, 113-21.

${ }^{12}$ Thomas Olesen, "The Muhammad Cartoons Conflict and Transnational Activism," Ethnicities 9, no. 3 (2009), 409-26.

${ }^{13}$ Lene Hansen, "The Politics of Securitization and the Muhammad Cartoon Crisis: A Post-Structuralist Perspective," Security Dialogue 42, no. 4-5 (2011), 365.

${ }^{14}$ Linde-Laursen, "Is Something Rotten in the State of Denmark?"; Nalborczyk A.S, "The Perception among Muslim Minorities of Host European Countries: Influence of Legal Status and Citizenship," Global Change Peace Secur. Global Change, Peace and Security 20, no. 1 (2008), 59-69; Eva Borreguero, "The Moors Are Coming, the Moors Are Coming! Encounters with Muslims in Contemporary Spain," Islam and Christian-Muslim Relations 17 , no. 4 (2006), 428-430.

${ }^{15}$ Hassner, "Blasphemy and Violence." 
however, predictable that Muslims, whose sacred symbol was humiliated, ${ }^{16}$ were outraged. But, Muslims living in different countries expressed their anger differently.

\section{Indonesian Islam in the reform era}

In Indonesia during the wake of the New Order regime's collapse have emerged new players with more conservative, if not radical, 'Islamist' ideologies visible in both political stage and public domain. Along with the tide of democratization in the country, Indonesians have enjoyed new freedom. Amid economic crisis and political chaos after Soeharto's loss of grip of power in the country, various opportunities for those who wanted to bring religious identity into politics came. The old spirit of 'Islamism,' which was once displayed by the Masyumi (the Council of Indonesian Muslim Associations) during Soekarno's era, was revived in a different manner and with a new globalized context. It is also noteworthy that after the September 11 incident, along with the war on terrorism waged by the US, Islamic radicalism gain momentum in the globally heated public discussion. ${ }^{17}$

Furthermore, the NU and Muhammadiyah, two major Islamic organizations in the country, did no longer dominate the public space in Indonesia during the reform period. Note that most of the new groups which came to participate in the public domain during the period showed Islamist ideologies, ${ }^{18}$ such as the FPI (Defenders Front of Islam), the HTI

\footnotetext{
${ }^{16}$ Keane, "Cartoon Violence and Freedom of Expression."

${ }^{17}$ Al Makin, "Pluralism versus Islamic Orthodoxy, the Indonesian Public Debate over the Case of Lia Aminuddin, the Founder of Salamullah Religious Cult," Journal of the International Yale Indonesia Forum Social Justice and Rule of Law: Addressing the growth of a Pluralist Indonesian Democracy (2011).

${ }^{18}$ Ismail Hasani and Bonar Tigor Naipospos, Dari Radikalisme Menuju Terorisme, Studi Relasi Dan Transformasi Organisasi Islam Radikal Di Jawa Tengah Dan DI Yogyakarta, Jakarta: Pustaka Media, 2012.
} 
(Hisbut Tahrir of Indonesia), the MMI (Mujahidin council of Indonesia), the FUI (Islamic Community Forum), Kumail (The Committee of Islamic Community for Anti-America and Anti-Israel). It is also noteworthy that the MUI (Indonesian Ulama Council), founded in 1975 aiming at bridging Muslims' and the government's interests, also played a greater role in the public domain during the reform period. Indeed, the MUI holds authority in the Indonesian Muslims' eyes through pronouncing religious edicts (fatwa). Unlike during the New Order era in which the MUI, like any other Islamic organizations, was managed to be silenced by the regime, in the reform era the Council often raised voices in response to various national issues from pornography to the increase of fuel's price. The speech delivered by the Pope Benedict XVI in $2005^{19}$ and the cartoons controversy were the themes upon which the MUI showed eagerness to comment. In this vein, the Council often sided with the conservative and radical groups, as the council did so in response to the Muhammad Danish cartoons.

\section{Reactions against the cartoons in national level}

Like the rest of Muslims in the Arab world, ${ }^{20}$ Indonesians also felt that with the publication of the Muhammad Danish cartoons their identity of being Muslims was under attack. For Muslims, not only is Muhammad a mere man who lived in the seventh century of the Arabian peninsula preaching Islam and revealing the Quran, but he also has become the most vital symbol of Muslims' identity throughout fifteen centuries. ${ }^{21}$ To

\footnotetext{
${ }^{19}$ Makin, "Benedict XVI and Islam."

${ }^{20}$ Ana Belen Soage, "The Danish Caricatures Seen from the Arab World," Totalitarian Movements $\mathcal{E}$ Political Religions 7, no. 3 (2006), 363-69; Jamila Hakam, "The "Cartoons Controversy': A Critical Discourse Analysis of English-Language Arab Newspaper Discourse," Discourse E⿱乛龰 Society 20, no. 1 (2009), 33-57.

${ }^{21}$ Andrew F March, "Speaking about Muhammad, Speaking for Muslims," Critical Inquiry 37, no. 4 (2011), 806-21.
} 
present the Indonesian president Susilo Bambang Yudhoyono's words, published by the International Herald Tribune, "It sends a conflicting message to the Muslim community: that in a democracy, it is permissible to offend Islam."22 Unsurprisingly, solidarity was shown from Muslims around the world, including Muslims in Indonesia, leading to violent riots and death threats.

It is interesting to see the way in which Hassner ${ }^{23}$ sheds light on the riots resulting from the protests staged by Muslims from different countries. To his analysis, authoritarian regimes were able to suppress the people's protests and demonstrations, which became less brutal. This was the case with many Middle Eastern and African countries ranging from Saudi Arabia, Jordan, Egypt, Yemen, Qatar, Sudan, Algeria, to Somalia. In the Muslim countries where civil liberties and political rights were exercised, riots occurred, due to the freedom exercised by the outrageous radical Muslims to whom the government responded late and yet haphazardly. Worse still, confrontation between demonstrators and security forces was visible. ${ }^{24}$ In Indonesia, unlike its Muslim neighbouring country Malaysia in which protests generated less chaotic mob, some radical groups who held mass rallies and ambushed Danish embassies were undeterred by the security forces' order.

Once again, after Soeharto's fall, mass demonstrations in the streets marked the emergence of freedom of expression in Indonesia. Many groups with different affiliations and voices had the same opportunity to show their stances. Yet one was often confused between the freedom of expression in the newly democratic country and anarchism. The case of

\footnotetext{
22 Susilo Bambang Yudhoyono, "Let's Try to Get beyond Caricatures - The New York Times," New York Time, International Herald Tribune, February 10, 2006, http:// www.nytimes.com/2006/02/10/opinion/10iht-edsby.html?_r=0.

${ }^{23}$ Hassner, "Blasphemy and Violence."

${ }^{24}$ Hassner, "Blasphemy and Violence"..., 24-25.
} 
Danish cartoons indicated the situation in which radical Muslim groups seized the moment. In defence of Islam, some groups-e.g. the FPI, the HTI, the MMI, the FUI, Kumail, and the PKS-were enraged by the cartoons publication, burning Danish flags, throwing eggs, tomatoes, and mud at the Danish embassy in Jakarta, threatening the cartoonists with death, and calling upon Muslims to boycott Danish products via SMS (short message system) of cell phones. ${ }^{25}$ The violent protests were also reported in Surabaya, where the local police failed to stop them. ${ }^{26}$

Despite their anger and protest, both Hasyim Muzadi and Din Syamsuddin, the NU's and Muhammadiyah's leaders respectively, tried to calm down the people. Syamsuddin urged Muslims not to 'overreact' against the cartoons. ${ }^{27}$ Muzadi, on the other hand, promised to the public to send a protest letter to the Danish embassy in Indonesia. ${ }^{28}$ By contrast, a MUI leader, Abdullah Syukri seems to justify the mass protests in the national and local levels throughout Indonesia, by saying that mass protests against the cartoons remained in the normal level and controllable. ${ }^{29}$

It is no exaggeration to conclude that all of the above conservative and radical groups showed no intention to see what the cartoons looked

${ }^{25}$ Asrori Karni S, Luqman Hakim Arifin, and Luky Setyarini, "Maaf Telat Tuan Karikatur Barat/Apology Is Too Late Mr. Western Cartoonists,” Gatra, February 11, 2006; G. A. Guritno and Luqman Hakim, "Arifin Reaksi Keras Ekspresi Bebas/Harsh Reactions towards Free Expression," Gatra, February 11, 2006; Rihad Wiranto and Nordin Hidayat, "Selamat Tinggal Danish/Goodbye Danish," Gatra, February 11, 2006.

${ }^{26}$ Hassner, "Blasphemy and Violence"..., 37.

${ }^{27}$ Aguslia Hidayah, Titis Setianingtyas, and Yanto Musthofa, "Muhammadiyah and NU Protest About Prophet Cartoon Contest,” Tempo Interactive, October 9, 2009, http:/ /www.tempointeractive.com/hg/nasional/2006/10/09/brk,20061009-85661,uk.html.

${ }^{28}$ NU Online, "Hasyim: Karikatur Nabi Muhammad Menghina Umat Islam/Hasyim: Muhammad Cartoons Insulted Islamic Community,” February 4, 2006, http:// www.nu.or.id/page/id/dinamic_detil/1/4091/War ta/ Hasyim__Karikatur_Nabi_Muhammad_Menghina_Umat_Islam.html.

${ }^{29}$ Liputan6.com, "MUI: Unjuk Rasa Karikatur Masih Wajar," liputan6.com, February 8, 2006, http://news.liputan6.com/read/117317/mui-unjuk-rasa-karikatur-masih-wajar. 
like, much less to understand the context in which the cartoons were drawn. After all, the images were not available in the Indonesian websites. The Rakyat Merdeka was the only newspaper in Indonesia which once displayed the cartoons-which then were responded to by protests. Although the pictures were blurred in red, the editor of the newspaper was forced to apologize publicly. ${ }^{30}$ The web Lapotuak.wordpress.com published the cartoons more clearly, which was soon under police's investigation and shut down. ${ }^{31}$

The Indonesian media also covered the full chronology of the cartoons controversy from its publications on September 30, 2005 to the outrageous reactions of Muslims around the world. ${ }^{32}$ This also played a role in further fuelling the Indonesian Muslims' anger. In reading these reactions against the Danish cartoons, the Indonesian context-which has played a critical role in shaping the opinions of the media, which, in turn, influenced the public's understanding of the issue-should be born in mind. ${ }^{33}$ Gadamer's hermeneutic in this regard is useful. According to Gadamer, the significance of a game involves a great role of the spectators, whose contribution in giving meaning to the game cannot simply be neglected. ${ }^{34}$ One may also relate this perspective to the theory of 'the

\footnotetext{
${ }^{30}$ Suwarjono, "Kartun Nabi Muh\}ammad Di Situs Rakyat Merdeka diprotes/Cartoon(s) of the Prophet Muh\}ammad in the Website of Rakyat Merdeka Were Protested," February 2, 2006, http://www.detiknews.com/read/2006/02/02/160720/531164/10/kartunnabi-Muh\}ammad-di-situs-rakyat-merdeka-diprotes.

31 "PKS: Tindak Tegas Pembuat Kartun Nabi/The PKS: Act Sternly against the Cartoonist(s) of the Prophet," Republika, November 20, 2008; "Polisi Selidiki Pemuatan Kartun Nabi Di internet/The Police Has Investigated the Display of the Cartoon(s) in the Internet," Republika, November 19, 2008.

${ }^{32}$ Ahmad Taufik, "Dari Sampul Buku Hingga demonstrasi/From Book Covers to Demonstrations," Tempo, February 19, 2006.

${ }^{33}$ Mark Peterson, "Making Global News: 'Freedom of Speech' and 'Muslim Rage' in U.S. Journalism," Contemporary Islam 1, no. 3 (2007), 247-64.

${ }^{34}$ Hans-Georg Gadamer, Hermeneutik I, Wahrheit Und Methode. Grundzüge Einer Philsophischen Hermeneutik, Tübingen: J. C. B. Mohr., 1986, 70-76, 115-116.
} 
death of the author', ${ }^{35}$ according to which those who have written pieces can no longer control their meaning. Instead, it is the audiences who later play a greater role in shaping the interpretation of the works, trough which new meanings are thus produced in new contexts. Particularly in the era of globalization and online media, the act of interpretation becomes a public deed, through which anyone can give new meanings to the works, regardless of the original intention of the authors. ${ }^{36}$ The case of Danish Muhammad cartoons is not exceptional. The cartoonists argued that they defended the values and principles of the freedom of speech and equal treatment to all citizens within the Danish context. Muslims around the world, however, reacted against them by showing their wounds due to the mockery of their 'symbol' and 'identity' that is the Prophet Muhammad. ${ }^{37}$

Although online media connected people around the globe, due to the fast transmission of information, it also sharpened the differences between those who delivered message within the original context and those who understood it from the other parts of the world far away. It is interesting to see the gap between the 'original' intention of the publication of the cartoons and the Indonesian audience's negative perception. Fleming Rose, ${ }^{38}$ the culture editor of Jyllands-Posten, argued that the publication is part of his goals to challenge 'moderate Muslims to speak out'.

35 Roland Barthes, Image, Music, Text, Essays, trans. Stephen Heath (London: Fontana, 1977), 148; Roland Barthes, "The Death of the Author," in The Rustle of Language, Berkeley: University of California Press, 1994, 55; Jonathan Culler, Roland Barthes, New York: Oxford University Press, 1983, 82.

${ }^{36}$ Laegaard, "Normative Interpreations of Diversity: The Muhammad Cartoons Controversy and the Importance of Context."

${ }^{37}$ Lene Hansen, "Theorizing the Image for Security Studies," European Journal of International Relations 17, no. 1 (2011), 64.

${ }^{38}$ Flemming Rose, "Why I Published Those Cartoons," The Washington Post, February 19, 2006, http://www.washingtonpost.com/wp-dyn/content/article/2006/02/17/ AR2006021702499.html. 
In this regard, Rose wrote that 'we are integrating you (Muslims) into the Danish tradition of satire because you are part of our society, not strangers'. ${ }^{39}$ The Indonesian audience, however, understood the cartoons differently, as this paper intends to show. In view of the harsh public reactions displayed in the printed and electronic Indonesian media, one may conclude that all Indonesians condemned the Danish twelve cartoons of the Prophet Muhammad in the same way. However, the reactions indeed varied, reflecting the ideologies the people embraced-whether they were radicals, conservatives, moderates, or liberals. ${ }^{40}$ My paper will delve into the arguments contained by thirteen selected pieces penned by Indonesian intellectuals and activists below.

\section{Thirteen op-ed pieces and one interview}

In this study, I choose thirteen op-ed pieces and one interview published by the online Indonesian media specifically in response to the Muhammad Danish cartoons. These responses represented various ideologies embraced by the Indonesian writers, intellectuals, and activists. In my analysis, I divide the opinions released by the Indonesian writers into two groups. The first group displays harsh reactions against the cartoons relying on theological arguments demonstrated by Thoriq, ${ }^{41}$ Hizbullah Mahmud, ${ }^{42}$ Syamsi Ali, ${ }^{43}$ and Adian Husaini. ${ }^{44}$ The second group shows more sober

${ }^{39}$ Flemming Rose, "Liquid Racism and the Danish Prophet Muhammad Cartoons," Current Sociology 58, no. 5 (2010), 675-92.

${ }^{40}$ Timothy P Daniels, "Liberals, Moderates and Jihadits: Protesting Danish Cartoons in Indonesia," Contemporary Islam 1 (2007), 231-46.

${ }^{41}$ Thoriq, "Mengapa Rasulullah Muh\}ammad Begitu Dibela umatnya/Why Has the Prophet Muh\}ammad [always] Been Defended by His People[?]," Hidayatullah, February 19, 2006.

${ }^{42}$ Hizbullah Mahmud, "Muh\}ammad Dan Hadiah Tahun baru/Muh\}ammad and the Gift of (Hijra) New Year,” February 14, 2006.

${ }^{43}$ Syamsi Ali, "Kartun Nabi Dan Reaksi umat/The Cartoons of the Prophet and the Muslim Community's Reactions," Hidayatullah, February 12, 2006, http:// www.hidayatullah.com/kolom/syamsi-ali/2759-kartun-nabi-dan-reaksi-umat-html. 
tone in expressing their opinions supported with reasoning and cultural arguments shown by Gunawan Mohamad, ${ }^{45}$ Laksmi Pamuntjak, ${ }^{46}$ Syu'bah Asa, ${ }^{47}$ Darmansjah Djumala, ${ }^{48}$ Budiarto Sambazy, ${ }^{49}$ Abdul Mukti Ro'uf, ${ }^{50}$ Syafiq Hasyim, ${ }^{51}$ Andy M. Bayuni, ${ }^{52}$ and Meidyatama Suryodiningrat. ${ }^{53}$

Thoriq and Mahmud were Indonesian students at the faculty of Shari'a, al-Azhar university, Cairo, whereas Ali is an imam (preacher) in the mosque of Islamic Culture Center, New York. Opinions by the three were published by online Hidayatullah.com, a media which is often used to voice conservatism and radicalism. Adian Husaini is an Indonesian radical journalist, who has notoriously attacked many Indonesian Muslim intellectuals, from moderate, Shi'ite, to liberals. ${ }^{54}$ He updated his personal blog regularly. Husaini's works-despite of poor quality in his use of logic in understanding other views-has been reposted in many Indone-

${ }^{44}$ Adian Husaini, "Mengapa Mereka Melecehkan Nabi Muh\}ammad SAW/Why Do They Insult the Prophet Muh\}ammad (piece and Blessing Be upon Him)?," February 11, 2006,http://www.adianhusaini.com/index.php?option=com_content $\&$ view=article $\mathcal{E}$ $\mathrm{id}=66$ : mengapa-mereka-melecehkan-nabi-Muh\}ammad-saw\& catid=34:cap\&Itemid=53.

${ }^{45}$ Mohamad Goenawan, "Karikatur," Tempo, February 19, 2006.

${ }^{46}$ Laksmi Pamuntjak, "Karikatur Dan kemarahan/The Cartoons and the Outrages," Tempo, February 2006.

${ }^{47}$ Syu'bah Asa, "Gambar Nabi, Pujaan Atau mainan/The Picture of the Prophet, a Venerable (prophet) or (mere) Toy," Tempo, February 19, 2006.

${ }^{48}$ Djumala, Darmansjah Djumala, "Meneropong Kartun Nabi Dari Uni Eropa/Telescoping the Cartoons from European Union," Gatra, March 4, 2006.

${ }^{49}$ Budiarto Sambazy, "Antara Barat Dan Asia/Between the West and Asia," Kompas, February 11, 2006.

${ }^{50}$ Abdul Mukti Ro'uf, "Memahami Kembali Hubungan Islam-Barat/Revisiting the Relation of Islam and the West," Jaringan Islam Liberal, February 20, 2006, http:// islamlib.com/id/artikel/memahami-kembali-hubungan-islam-barat/.

${ }^{51}$ Syafiq Hasyim, "Multikulturalisme Baru Barat-Islam/A New Multiculturalism (for) West and Islam," Kompas, February 10, 2006.

${ }^{52}$ Endy M Bayuni, "Cartoon Controversy Is Bad Press for Free Speech," The Jakarta Post, February 6, 2006.

${ }^{53}$ Suryodiningrat, Meidyatama Suryodiningrat, "Malice or Free Speech in Danish Cartoon?," The Jakarta Post, February 16, 2006.

${ }^{54}$ Makin, "Benedict XVI and Islam." 
sian personal websites, whose affiliations are either conservative or radical groups, such as the PKS activists. The PKS groups outside Indonesia, such as in Germany, have actively used the online media, which features Husaini's views, to propagate their conservative ideology. Nevertheless, these writers-Mahmud, Ali, and Husaini-all rely on theological foundation apparently to legitimize the actions of their angry fellow Muslims, adopting an apologetic attitude in defence of Islam. ${ }^{55}$ In doing so, they based their judgements on their interpretation of some verses of Quran, hadith (tradition), and some episodes of the sira (literature on the life of the Prophet Muhammad). Seen from the sources, they are conservative Muslims with traditional style. Condemnation, curses, and fury embellish their writings.

Those who hold 'cultural arguments,' on the other hand, demonstrated more sophisticated reasoning equipped with various sources. Their voices are not homogenous. Their interpretation of the pictures is equipped with hermeneutical effort in rendering meaning to these satirical depictions of the Prophet. Some attempts-e.g. those made by Djumala, Mohamad, Pamuntjak-were indeed made to grasp the context wherein the cartoons were published. Interestingly, the case of the cartoons served as lesson for some writers-Mohamad, Pamuntjak, Rouf, Hasyim-calling upon Muslims to perform self-reflection as to whether or not they are committed to fair judgement of the 'West.' Rather than merely curses poured upon the cartoonists, Danish government, and society altogether, the door of dialogue was also apparently open to these writers.

\footnotetext{
${ }^{55}$ Here we can perhaps draw the relation between opinions posted in the media and various ideologies embraced by and attitude of the people. Daniels, "Liberals, Moderates and Jihadits: Protesting Danish Cartoons in Indonesia"; Makin, "Benedict XVI and Islam"; and the relation between online media and the off line actions Georan Larsson, "CyberIslamophobia? The Case of WikiIslam," Contemporary Islam 1, no. 1 (2007), 53-67.
} 
Mohammad is a leading Indonesian journalist, whose fame rest in his essays published weekly by the magazine Tempo, where Pamuntjak and Asa also work. Besides writing, Mohamad gave patronage to young Muslim intellectuals, such as Ulil Abshar Abdallah and Lutfie Assyaukanie, to develop liberal and progressive ideas in Utan Kayu, Jakarta. The Islamic Liberal Network (JIL), which published Ro'uf's opinion and Assyaukanie's interview with Mohamad, is the medium of liberal Islam's voices, often countering views published by the Hidayatullah.com which propagates radicalism and conservatism. Kompas, which publishes Hasyim's and Sambazy's opinions, is the largest daily newspaper in Indonesia, previously associated with Catholicism, but later gave room to the ideas of moderate Islam in Indonesia. The first English daily newspaper The Jakarta Post, which preserves Bayuni's and Suryodiningrat's opinions, is the boldest newspaper in Indonesia in unleashing criticism to both the government and Islamic radicalism during the reform era. Whereas Kompas reserves a certain careful attitude in releasing news with sensitive issues to both Muslims and the government, The Jakarta Post is the place where free expression can be guaranteed. It stands to reason to argue that the Kompas uses the Indonesian languages easily understood by Indonesians, while The Post's readers are 'elite' English speakers. Bayuni was the editor in chief of The Post. Whereas Hasyim was an NGO activist at the International Center for Islam and Pluralism (ICIP), who currently was still finishing his Ph.D in Berlin, Germany, Djumala was an Indonesian diplomat based in Brussels, Belgium.

\section{Theological arguments}

Outrageous reactions against the publication of the Danish cartoons with theological arguments are preserved in the works of Thoriq, Hizbullah Mahmud, Syamsi Ali, and Adian Husaini, all of whom represent those 
who show their offence publicly against the cartoonists in more or less the same way. Notwithstanding different verses of Quran, Hadith, and episodes of the sira they pick to support their view, they all defend the truth of Islam and the venerable position of the Prophet Muhammad in the eyes of Muslims. Additionally, all assault Western values, including the freedom of speech, their irreligious character, and hegemonic imperialism.

\section{Condemning the blasphemy}

Four writers-Thoriq, ${ }^{56}$ Mahmud,,${ }^{57}$ Ali, ${ }^{58}$ and Husaini ${ }^{59}$-show their anger that these Danish cartoonists, who committed blasphemy, deserve curses and even punishment. Thoriq unleashes attack on the cartoonists that they have vilified the Prophet, whom all Muslims highly venerate. Thoriq adds that the Prophet's deeds are examples for all Muslims. His words, which become the second source for Muslims' religiosity, have been carefully transmitted in numerous hadith collections. Thoriq, in this vein, cites a tradition, showing 'Umar b. Khattāab's tender love of the Prophet ${ }^{60}$ which, Thoriq says, represents that of all Muslims. Mahmud also subscribes to the view that the publication of the cartoons is similar to the evil deeds of the previous enemies of Islam, such as the people of T⿳a ' if and the Quraysh, who scorned the Prophet's call to Islam.

Ali and Husaini seem to see the 'mocking' pictures, on which therefore certain parts of their comments are made. Ali, in this regard, is

56 Thoriq, "Mengapa Rasulullah Muhammad Begitu Dibela umatnya/Why Has the Prophet Muhammad [always] Been Defended by His People[?]."

${ }^{57}$ Mahmud, "Muhłammad Dan Hadiah Tahun baru/Muhammad and the Gift of (Hijra) New Year."

${ }^{58}$ Ali, "Kartun Nabi Dan Reaksi umat/The Cartoons of the Prophet and the Muslim Community's Reactions."

${ }^{59}$ Husaini, "Mengapa Mereka Melecehkan Nabi Muhammad saw./Why Do They Insult the Prophet Muhammad (piece and Blessing Be upon Him)?".

${ }^{60}$ Bukhārì, Șaḥih (Istanbul: Dār wa Mațābi‘ al-Sha'b, n.d.), vols. 5, 8. 
extremely angered by the cartoon which depicts the Prophet with a bomb in his turban. According to Ali, not only does this picture exhibit a gross blasphemy, it also shows the cartoonists' wild imagination. Thus, all of these pictures, like the visualization of Jesus and Maria in Christian traditions, contain nothing but deceptive portrayals. Moreover, the picture of Muhammad's head with a bomb, according to Ali, is a false accusation against the Prophet of being a suicide bomber.

Husaini comments on another cartoon depicting the Prophet who shouts, "Stop stop, we ran out of virgins!" This, for Husaini, implies nothing but an extreme cruelty of the cartoonists (biadab dan keterlaluan), who have made the honourable Prophet of Islam as their mere toy (mainan), laughable stock (bahan tertawaan), and the subject of scorn (bahan ejekan)which, Husaini further argues, hurt the feeling of Muslims (perasaan pedih). For this, Husaini calls upon Muslims to perform jihād (jihad melawan sebuah kezaliman yang teramat sangat).

\section{The Quran has already spoken about 'their deeds'}

Interestingly, according to Thoriq, Ali, and Husaini, the Quran has spoken about the cartoonists' evil deeds. In other words, they regard the act of cartoonists as similar to the immoral deeds already pinpointed by the Scripture fifteen centuries ago. Thoriq, for instance, presents Q. 33: 6, which preserves the story of Noah who was confronted by the attacks of his people. In other words, the wicked acts committed by the cartoonists are the same as those of the people of Noah (Q. 7: 65-66), the unbelievers of 'A $\mathrm{d}$, Thamūd, and Midian, all of whom committed the same pattern of malicious behaviours against their prophets. This recalls the way in which Sayyid Qutb read the narrative of Quran, in which some protagonist and antagonist characters, such as Moses and Pharaoh, were projected to his own political experience in facing the modern Egyptian re- 
gime. Moses represents Qutb's own struggle, whereas Pharaoh his political enemy, Gamal Abdel Nasser. ${ }^{61}$

Furthermore, Thoriq sees the Danish cartoons as the media, in which 'the West' exercised their dictatorship. Those who disagree with the 'West,' Thoriq simplifies, would be annihilated, with either war or embargo, as the 'West' always demands Muslims' loyalty and obedience. This stance also reflects that of Qutb.

\section{Recalling the sirra}

Besides re-enacting the stories of Quran, the proponents of theological arguments recall Muhammad's biography (sira). In defending the virtuous character of the Prophet, Mahmud and Ali present an episode in the sira, according to which the Prophet was scorned by the Meccans and the people of TTa' if. The Prophet, however, had no intention to take any revenge on them. Instead, he prayed to God for them. Mahmud also recalls the accounts of the conquest of Mecca, which, Mahmud highlights, was performed via a peaceful tactic. No bloodshed occurred during this event. ${ }^{62}$ Ali writes further that even before Muhammad was appointed as a prophet, he was known among his people for his peace initiative. During the reconstruction of the Ka'ba, some Arab tribes squabbled with each other on the issues of who would lay the black-stone in its place. The Prophet found a solution-according to which Muhammad put the stone in a cloak, which these tribes held together, and then the Prophet put the stone in its place. ${ }^{63}$

${ }^{61} \mathrm{Al}$ Makin, "Modern Exegesis on Historical Narratives of the Qur'an, the Case of 'Ad and Thamud according to Sayyid Qutb in His Fi Zilal Al-Qur'an", McGill University, 1999.

${ }^{62}$ Ali, "Kartun Nabi Dan Reaksi umat/The Cartoons of the Prophet and the Muslim Community's Reactions."

${ }^{63}$ Ibn Hisham, Al-Sirra al-Nabawiyya, Ed. Mustafā al-Saqā, Ibrahīm al-Abyārì, and 'Abd al-

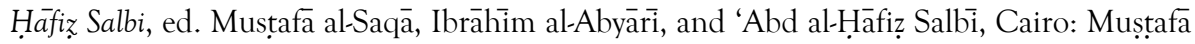

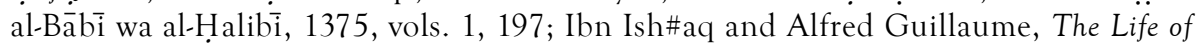


Ali also presents the account of the Hudaybiyya treaty, whose content the Prophet obeyed, although it was disadvantageous for Muslims. All these historical records prove that the Prophet is a peace lover, whose examples all Muslims have followed. However, the cartoonists expected Muslims to react harshly to their works in order to justify their stereotype suggesting that all Muslims are hardliners, irrational, and emotional. ${ }^{64}$

The above arguments by showing Muhammad's virtuous image portrayed in the sira sound promising to counter his later horrific image in the hands the Danish cartoons. But, there was a gap between the opinions and reality. If Muhammad was depicted as a peaceful prophet, one may ask why the Muslims' protests against the cartoons in Indonesia became chaotic and even leading to violence.

\section{Glimpse at the 'twisted' context}

In the opinions released by the proponents of theological arguments the Danish and European context are twisted. To begin with, Ali and Husaini comment on the freedom of expression, on which the arguments for

Muhammad, A Translation of Ishâaq's Sirat Rasūl Allāh, with Introd. and Notes by A Guillaume, Karachi: Oxford University Press, 1980, 86.

${ }^{64}$ However, this apologetic interpretation contains simplification. In fact, few Meccans, e.g. 'Abdalla b. Sa'd, 'Abdalla b. Khațtāl, and Miqyas b. Hubāba who hid behind the curtain of the Ka'ba during the conquest of Mecca, were indeed killed. Ibn Hishām, Al-Sira Al-Nabawiyya, Ed. Mustafä Al-Saqā, Ibrahim Al-Abyäri, and 'Abd al-Hä́fiz Salbi, vols. 2, 409; Ibn Ishaqa and Guillaume, The Life of Muhammad, A Translation of Ishāq's Sîrat Rasûl Allâh, with Introd. and Notes by A Guillaume, 550-551; Ali's interpretation, however, sounds simplistic and apologetic. Compare with what scholars have discussed on this issue. Gerald R. Hawting, "Al-Hudaybiyya and the Conquest of Mecca," Jerusalem Studies in Arabic and Islam 8 (1986): 1-23; Michael Lecker, "The Hudaybiyya Treaty and the Expedition against Khaybar," Jerusalem Studies in Arabic and Islam 5 (1984), 1-11; Muhammad Qasim Zaman, "Maghâzî and the Muaddithûn: Reconsidering the Treatment of 'Historical' Materials in Early Collections of Hadith," International Journal of Middle East Studies 28, no. 01 (1996), 1-18; Reuven Firestone, "Disparity and Resolution in the Quranic Teachings on War: A Reevaluation of a Traditional Problem," Journal of Near Eastern Studies 56, no. 1 (1997), 1-19. 
publishing the cartoons have been based. Ali questions the meaning of freedom of expression as perceived by the 'West.' For Ali, insulting religious leaders, such as Muhammad, Jesus, and Moses, is not what the 'freedom of speech' means. Additionally, according to Ali, the meaning of this term, which excludes deeper consideration and responsibility, confused the 'West.' Ali goes further that freedom accompanied by hurting others' feeling is misleading. ${ }^{65}$

Additionally, Husaini exaggerates the bad situation in Europe, whose Christian population has always been haunted by the rapid development of Islam. The fear of immigrants, associated with Islamization of Europe, has also been prevalent in the continent. This fear has led them to alienate Muslims with the intention to expel them from Europe-a situation which has also marked Denmark. Husaini in this vein attacks the Danish queen, Margrethe II, who designates Islam as a serious challenge to Western culture which should be confronted. The queen said: "We have to show our opposition to Islam and we have to, at times, run the risk of having unflattering labels placed on us because there are some things for which we should display no tolerance,"....She also said: "We are being challenged by Islam these years - globally as well as locally." ${ }^{66}$ In the end, Husaini uses Bjorn Moller's view posted in the website of The Christian Science Monitor to lend weight to his view that these cartoons were made to provoke sentiments against Muslims in order to alienate and label them as fanatics. ${ }^{67}$

${ }^{65}$ P Sturges, "Limits to Freedom of Expression? Considerations Arising from the Danish Cartoons Affair," IFLA JOURNAL 32, no. 3 (2006), 181-188.

${ }^{66}$ Islamonline.net, "Danish Queen Says Islam Poses Global Threat," April 15, 2005, http://www.islamonline.net/English/News/2005-04/15/article02.shtm1; Andrewcusack.com, "Queen Margrethe: We Must Show Our Opposition to Islam," February 8, 2006, http://www.andrewcusack.com/2006/02/08/queen-margrethe/.

${ }^{67}$ James Brandon, "Danish Editor Tests Right to Violate Muslim Taboos," November 10, 2005, http://www.csmonitor.com/2005/1110/p01s01-woeu.html. 


\section{Calling for Muslims'solidarity}

As mentioned earlier, solidarity is part of the globalized ummah. ${ }^{68}$ Indeed, Muslims' reactions from around the world were due mainly to their solidarity in response to the other members of the ummah far away in Europe who were treated unfairly. In this vein, not only do Thoriq, Mahmud, Ali and Husaini share such solidarity, they also call upon the rest of Muslims for the sake of ummah's unity and cohesion to react to the Danish cartoons. Whereas Thoriq condemns those who refused to apologize publicly and those who republished the cartoons, Mahmud reminds all Muslims about their brotherhood as mentioned in a prophetic Tradition. Husaini warns Muslims not to remain silent. Insulting the Prophet in Islam, Husaini insists, led to capital punishment, i.e. the death penalty. On the other hand, Ali asks Muslims to react in accordance with the Prophet's noble examples. Apparently, the radicals failed to heed this advice.

\section{Cultural arguments}

Cultural arguments were marked by the attempts of the below Indonesian writers to understand the Danish and European contexts. This can be seen in the pieces penned by Sambazy, ${ }^{69}$ Hasyim,${ }^{70}$ Djumala, ${ }^{71}$ Pamuntjak, ${ }^{72}$ Mohamad, ${ }^{73}$ Asa, ${ }^{74}$ Ro'uf, ${ }^{75}$ Bayuni, ${ }^{76}$ and Suryodiningrat ${ }^{77}$

\footnotetext{
${ }^{68}$ Ibrahim, "The Mediated 'Ummah' in Europe: The Islamic Audience in the Digital Age”; Saunders, "The Ummah as Nation"; March, "Speaking about Muhammad, Speaking for Muslims."

${ }^{69}$ Sambazy, "Antara Barat Dan Asia/Between the West and Asia."

${ }^{70}$ Hasyim, "Multikulturalisme Baru Barat-Islam/A New Multiculturalism (for) West and Islam."

${ }^{71}$ Djumala, "Meneropong Kartun Nabi Dari Uni Eropa/Telescoping the Cartoons from European Union."

72 Pamuntjak, "Karikatur Dan kemarahan/The Cartoons and the Outrages."

${ }^{73}$ Goenawan, "Karikatur"; Mohamad Goenawan, "Goenawan Mohamad: Reaksi Berlebihan Merepotkan Muslim Eropa/Goenawan Muhamad: Harsh Reaction Leads to
} 
who all recall the Danish and European political and societal situation, wherein the cartoons were drawn. Then, they examine the widening gap between Islam and the West, particularly in the aftermath of the $11^{\text {th }}$ September tragedy. Their criticism, however, was not merely directed at the Danish, European society, and the 'West' in general, but also at Muslims themselves who often show their unfair judgement of the 'West.' Apparently, these writers attempt to balance their opinions that hatred and mockery did not exclusively belong to the Europeans, but both can reside in the hearts and actions of Indonesian Muslims, who often showed their misperception of the West.

\section{Interpreting the 'mocking' pictures}

Those who rely on reasoning and draw cultural arguments also dare to discuss the images of the cartoons openly. Three writers-Pamuntjak, Goenawan Mohamad, and Asa-comment on the pictures specifically, e.g. one depicting Muhammad's head attached with a bomb and the other showing him yelling: "stop stop, we ran out of virgins." According to Pamuntjak, the first picture clearly associates Islam with violence, thus insulting all Muslims. ${ }^{78}$ For Pamuntjak, this picture indicates nothing but an absolutist attitude of the cartoonist. The second picture, Pamuntjak writes, annoys the feminists, from whose perspective one may see that the cartoon only perpetuates the unjust position of women, who will

Difficult Position of European Muslims," Jaringan Islam Liberal, February 20, 2006, http:/ /islamlib.com/id/artikel/reaksi-berlebihan-merepotkan-muslim-eropa/.

${ }^{74}$ Asa, "Gambar Nabi, Pujaan Atau mainan/The Picture of the Prophet, a Venerable (prophet) or (mere) Toy."

${ }^{75}$ Ro'uf, "Memahami Kembali Hubungan Islam-Barat/Revisiting the Relation of Islam and the West."

${ }^{76}$ Bayuni, "Cartoon Controversy Is Bad Press for Free Speech."

77 Suryodiningrat, "Malice or Free Speech in Danish Cartoon?".

${ }^{78}$ Goenawan, "Karikatur.” 
serve as mere rewards for the suicide bombers in the hereafter.

In showing his criticism to the cartoons, Mohamad says that it is true that all cartoons are made for the purpose of mockery. However, what the Danish cartoonists have depicted is a stereotype. The Muhammad whom these cartoonists draw is not the Prophet whom all Muslims have always imagined. These cartoons convey nothing but the cartoonists' own fear, stereotype, and insult to the "other"-an attitude that the Danes in general have adopted, to various degrees.

On the other hand, according to Asa, the pictures seen in the cartoons are only 'wild imagination'. ${ }^{79}$ For Asa, were the Prophet himself still alive, he would have just smiled in seeing the cartoons and would have let these cartoonists receive lessons from their own community. In this vein, Asa tries to present Muhammad's 'true image,' not merely condemning the vilifying pictures shown in the Danish cartoons.

Interestingly, Pamuntjak, on the other hand, summons Muslims to learn from the Christian tradition in drawing Jesus, whose depictions vary due to various perspectives of the painters and to the local contexts in which the painters live. In fact, not all pictures show the positive side of Jesus, but this does not decrease his position in the heart of true Christians. Sober reactions to the cartoons are thus advisable. ${ }^{80}$

\section{Imagining the Danish and European context}

To understand the local Danish and European context, Djumala specifically underlines the problem of religious and ethnic integration in many European countries. Djumala takes the riot in Paris as an example of

\footnotetext{
${ }^{79}$ Ali, "Kartun Nabi Dan Reaksi umat/The Cartoons of the Prophet and the Muslim Community's Reactions."

${ }^{80}$ Asa, "Gambar Nabi, Pujaan Atau mainan/The Picture of the Prophet, a Venerable (prophet) or (mere) Toy"; Suryodiningrat, "Malice or Free Speech in Danish Cartoon?".
} 
anti-Muslim sentiment. ${ }^{81}$ In the aftermath of the tragedy of $11^{\text {th }}$ September, the sentiments against Islam in Denmark, like in other Western countries, also grew. ${ }^{82}$ The Danish cartoons, according to Djumala, were published against this backdrop.

Mohamad also detects a strong conservatism in Denmark. ${ }^{83}$ He takes the case of two Lutheran pastors, Jesper Langballe and Soren Krarup, members of Danish parliament who said that Islam is like a cancer in Denmark. ${ }^{84}$ Mohamad likens their conservatism to that of the MUI (Indonesian Ulema Council), all of whom stand against multiculturalism. Note that the council pronounced various edicts containing counterproductive elements to pluralism, such as an edict prohibiting pluralism and liberalism (h\}aram) and other edicts banning minority sects branded heretics, such as Ah\}madiyyah, Shi'ite, and Lia Eden Salamullah group. ${ }^{85}$

\section{The 'West' and the 'East' relation beyond the cartoons}

For some Indonesian writers, the cartoons controversy recalled the West and East relation. Hasyim, for example, sees the Danish cartoons still

${ }^{81}$ The series of riots took place in Clichy-sous-Bois, France, between October and November, 2005. It seems that Djumala exaggerates the 'Islamic factor' which led to these riots-a point originally touched upon by Ariane Bernard, who writes that "majority of the youths committing the acts are Muslim, and of African or North African origin". The head of the Direction centrale des renseignements généraux, however, found no Islamic factor in the riots. Ariane Bernard, "10 Officers Shot as Riots Worsen in French Cities," New York Time, November 5, 2005, http://nytimes.com/2005/11/07/international/europe/ 07france.html?pagewanted=2\&ei=5094\&en=573c9c6c59c15188\& hp\&ex=1131426000\& partner=homepage.

${ }^{82}$ Pamuntjak, "Karikatur Dan kemarahan/The Cartoons and the Outrages"; Goenawan, "Goenawan Mohamad: Reaksi Berlebihan Merepotkan Muslim Eropa/Goenawan Muhamad: Harsh Reaction Leads to Difficult Position of European Muslims"; Goenawan, "Karikatur"; Sambazy, "Antara Barat Dan Asia/Between the West and Asia."

${ }^{83}$ Pamuntjak, "Karikatur Dan kemarahan/The Cartoons and the Outrages."

${ }^{84}$ Jytte Klausen, "Rotten Judgment in the State of Denmark," February 8, 2006, http:/ /www.salon.com/opinion/feature/2006/02/08/denmark/index1.html.

${ }^{85}$ Makin, "Pluralism versus Islamic Orthodoxy, the Indonesian Public Debate over the Case of Lia Aminuddin, the Founder of Salamullah Religious Cult." 
reflect the classical literature produced by the West which has often portrayed Islam in a negative manner. However, Hasyim also gives balance judgement by recalling that the East also holds a common misperception of the West. ${ }^{86}$ Hasyim concludes that the making of the cartoons is the case in which the Western Islamicists have failed to promote the positive side of Islam in their own society. Additionally, Ro'uf ${ }^{87}$ pinpoints the gap which has widened between the West and the East in the aftermath of the $11^{\text {th }}$ September incident. ${ }^{88}$ The publication of the Danish cartoons made the gap wider.

Mohamad, ${ }^{89}$ on the other hand, notes that the cartoons controversy is not about the West and the East; nor is it about the 'clash of civilizations' ${ }^{90}$-but it rather indicates 'the clash between fundamentalists' ${ }^{91}$ Fundamentalism should not be attributed to Muslim society. It also emerged in other faiths and religious communities. Fundamentalism is a common problem shared by all humankind, against which all should fight.

In response to the Muslims' riots across the world protesting against the cartoonists, Mohamad remarks their inferior feeling. He notes that

${ }^{86}$ Ro'uf, "Memahami Kembali Hubungan Islam-Barat/Revisiting the Relation of Islam and the West"; Goenawan, "Goenawan Mohamad: Reaksi Berlebihan Merepotkan Muslim Eropa/Goenawan Muhamad: Harsh Reaction Leads to Difficult Position of European Muslims"; Hasan Hanafi, Muqaddima Fi 'Ilm Al-istighräb/Introduction to the Science of the West, Bayrūt: al-Muassasah al-Jāmi'iyah li al-Dirāsāt wa al-Tawzi'., 1992; Y Wahyudi, "Arab Responses to Hasan Hanafi's Muqaddima Fi I ' lm Al-Istighrab,” Muslim World 93 (2003), 233-48.

${ }^{87}$ Ro'uf, "Memahami Kembali Hubungan Islam-Barat/Revisiting the Relation of Islam and the West."

${ }^{88}$ Sambazy, "Antara Barat Dan Asia/Between the West and Asia"; Pamuntjak, "Karikatur Dan kemarahan/The Cartoons and the Outrages"; Goenawan, "Karikatur."

${ }^{89}$ Goenawan, "Goenawan Mohamad: Reaksi Berlebihan Merepotkan Muslim Eropa/ Goenawan Muhamad: Harsh Reaction Leads to Difficult Position of European Muslims."

${ }^{0}$ Sambazy, "Antara Barat Dan Asia/Between the West and Asia"; Pamuntjak, "Karikatur Dan kemarahan/The Cartoons and the Outrages"; Bayuni, "Cartoon Controversy Is Bad Press for Free Speech.”

${ }^{91}$ Anver Emon, "On the Pope, Cartoons, and Apostates," Journal of Law and Religion 22 (2007), 303-21. 
almost all Muslim countries are former colonies of the West, leading to Muslims' feeling of inferiority complex, which, among other things, has fuelled their anger, which was not solely directed at the cartoons, but at the West in general. ${ }^{92}$ It is unsurprising that many Muslims, Mohamad goes further, still felt being threatened by the more powerful 'West,' although it is never clear which 'West' they mean. Mohamad in this vein is critical that many Muslims hold a 'conspiracy theory', by which the West was often seen as a single monolithic power bent on destroying Islam.

\section{Weakening the struggle for the freedom of expression and multiculturalism}

There is another blunder in the publication of the cartoons, which, according to many Indonesian writers, will only weaken the struggle for the free speech and multiculturalism. For Bayuni, the grave mistake committed in this publication is that even some proponents of free speech will distance themselves from it. The public has therefore been forced to the position of either condemning or defending the publication, allowing almost no middle ground stance. Bayuni goes further that fundamentalists ${ }^{93}$ will easily point to these cartoons "as examples of what freedom of expression can do to society." To quote Bayuni's words, "they will constantly refer to these cartoons as a compelling example of why free speech is bad for society."

Sambazy, on the other hand, points to the twisted meaning of freedom of speech in the arguments of the proponents of the Danish car-

\footnotetext{
${ }^{92}$ Marion G Müller and Esra Özcan, "The Political Iconography of Muhammad Cartoons: Understanding Cultural Conflict and Political Action,” April 2007, http:// www.apsanet.org/imgtest/PSApr07Muller_Ozcan.pdf.

${ }^{93}$ Ali, "Kartun Nabi Dan Reaksi umat/The Cartoons of the Prophet and the Muslim Community's Reactions"; Husaini, "Mengapa Mereka Melecehkan Nabi Muhammad SAW/ Why Do They Insult the Prophet Muhammad (piece and Blessing Be upon Him)?".
} 
toons. In fact, their publication shows nothing but 'racism' ${ }^{\text {'4 }}$ and the adoption of 'double standards' attitude. ${ }^{95}$ Furthermore, Sambazy also shows the way the work of Philippe J. Rushton received some protests in the 'West'. ${ }^{96}$ Among the conclusion drawn by Rushton is that the Caucasians have lower intelligence than that of the Mongoloid Asians. To Sambazy, the insulting aspect in the cartoons was even worse than Rushton's observation.

In line with Sambazy, Suryodiningrat argues that the publication of cartoons has nothing to do with the freedom of expression, but with 'malice.' The publication, to Suryodiningrat, does not offer a form of satire-which refers to a social critique-but a mere vilification.

\section{Conclusion}

This paper does not specifically addresses the twelve Muhammad Danish cartoons and the cartoonists, whose use of symbolism has malicious ends by vilifying the subjects. Rather, this paper focuses on the way in which the Indonesian public reacted against the publication of the mocking cartoons and the way in which they gave meanings to them. In fact, the twelve cartoons have triggered heated global public debates, between East and West, Muslim world and Europe. Furthermore, the twelve images vilifying Muhammad have caused a crisis, whose solution needed political negotiation, trans-national communication, and diplomacy. In Indonesia, in the aftermath of Soeharto's fall from power, from which the reform era started, the public domain has become a place where every-

\footnotetext{
${ }^{94}$ Pamuntjak, "Karikatur Dan kemarahan/The Cartoons and the Outrages"; Bayuni, "Cartoon Controversy Is Bad Press for Free Speech"; Suryodiningrat, "Malice or Free Speech in Danish Cartoon?"; Goenawan, "Karikatur."

${ }_{95}$ Goenawan, "Karikatur"; Pamuntjak, "Karikatur Dan kemarahan/The Cartoons and the Outrages."

${ }^{96}$ J. Philippe Rushton, Race, Evolution, and Behavior: A Life History Perspective (New Brunswick, N.J., USA: Transaction Publishers, 1995).
} 
one is set free to convey opinions-a new freedom which the Indonesians never enjoyed during the New Order period. All in all, once the images of the cartoons reached Indonesian audience, through the online media, various different interpretations were displayed in the public. In the newly reform period of Indonesia where the process of democratization was interestingly concomitant with the rise of radicalism, responses to the Danish cartoons featured warring different ideologies in the public. Many groups raised their voices, through which they defended their stances and ideologies. It is also true that the reaction against the cartoons represented political, social, and religious situation in the country. Additionally, the reactions portrayed the battle in the public sphere, where various ideologies competed against each other in the newly free public domain.

Once again, for the Indonesian audiences, the Danish Muhammad cartoons were not just cartoons with their humorous, offensive, and mocking elements by exaggerating certain parts of the subjects. For the above Indonesian writers, on the other hand, these cartoons had to be responded to seriously, as they were related to many crucial issues: faith, East-West relations, freedom of speech, and multiculturalism.

Nonetheless, after reading the fourteen selected pieces above by Indonesian intellectuals and activists, we can find two tendencies in their arguments: arguments returning to theological formulation and the others relying on cultural values. Those who use theological arguments regard the cartoonists and the West as a single entity, which these cartoonists represent as wanting only to destroy Islam. For them, the West is only one monolithic entity; so is Islam. The proponents of theological arguments seem to serve as the mouthpieces for those who protested against the cartoons violently.

With the spirit of Islamism, radicals demonstrated nothing but outrage. Their standard of morality, by which the sacred symbol of 
Muhammad was defended, was under assault. This was indeed the opportunity that they could seize in order to both promote their Islamist ideology and attack those who opposed them. Furthermore, they claimed that their voice represent Islam and all Muslims in general. In fact, most of Indonesian Muslims, ignoring the case which was not their immediate interest, were reluctant to take their position. It can be said that they are silent moderate Muslim majority.

It is true that the proponents of cultural arguments, who also declared themselves as the defenders of free speech and multiculturalism, denounced the publication of the cartoons, branding them as signs of racism, xenophobia, and discrimination. However, their arguments are not simplistic. In order to grasp the Danish, European, and Western contexts, they draw various sources including history, art, traditions, literary works, political, sociological, and economic factors. Notwithstanding their critical attitude to the cartoons, their criticism is directed even at their own society, i.e. self-reflection through which they recalled Muslims' misperception of the West.

However, it appears that those who hold cultural arguments still failed to draw a clear distinction between Islam as 'a theological system' and 'Muslims.' So far self-criticism from the above writers is directed at Muslims' attitude to the West, but not at Islamic theology. In fact, they always mention the term 'Islam' to refer to both Islamic theology and Muslims. This, however, does not address a more critical issue, that is Muslims' uncritical attitude to their own religion with justification of Islamic theology. In the public debates of the Muhammad Danish cartoons, one fails to find a serious criticism to Islamic theology. In this vein, moderate and liberal Muslim still failed to differ themselves from their conservative and radical counterparts in that Islamic theology remains untouched. 


\section{Bibliography}

Ali, Syamsi, "Kartun Nabi Dan Reaksi umat/The Cartoons of the Prophet and the Muslim Community's Reactions." Hidayatullah, February 12, 2006. http://www.hidayatullah.com/kolom/syamsi-ali/2759-kartunnabi-dan-reaksi-umat-html.

Andrewcusack.com. "Queen Margrethe: We Must Show Our Opposition to Islam," February 8, 2006. http://www.andrewcusack.com/2006/02/ 08/queen-margrethe/.

Asa, Syu'bah, "Gambar Nabi, Pujaan Atau mainan/The Picture of the Prophet, a Venerable (prophet) or (mere) Toy." Tempo, February 19, 2006.

Barthes, Roland. Image, Music, Text, Essays. Translated by Stephen Heath. London: Fontana, 1977.

Barthes, Roland, "The Death of the Author." In The Rustle of Language. Berkeley: University of California Press, 1994.

Bayuni, Endy M., "Cartoon Controversy Is Bad Press for Free Speech." The Jakarta Post, February 6, 2006.

Bernard, Ariane, "10 Officers Shot as Riots Worsen in French Cities." New York Time, November 5, 2005. http://nytimes.com/2005/11/07/international/europe $/ 07$ france $\cdot h t m l$ ? pagewanted $=2 \& \mathrm{ei}=5094 \& \mathrm{en}=573 \mathrm{c} 9 \mathrm{c}$ 6c59c15188\& $\mathrm{hp} \&$ ex $=1131426000 \&$ partner=homepage.

Borreguero, Eva, "The Moors Are Coming, the Moors Are Coming! Encounters with Muslims in Contemporary Spain." Islam and Christian-Muslim Relations 17, no. 4 (2006): 417-32.

Brandon, James, "Danish Editor Tests Right to Violate Muslim Taboos," November 10, 2005. http://www.csmonitor.com/2005/1110/p01s01woeu.html.

Bukhāri. Sahịh. Istanbul: Dār wa Mațābi' al-Sha'b, n.d.

Culler, Jonathan. Roland Barthes. New York: Oxford University Press, 1983.

Daniels, Timothy P., "Liberals, Moderates and Jihadits: Protesting Danish Cartoons in Indonesia." Contemporary Islam 1 (2007): 231-46.

Djumala, Darmansjah, "Meneropong Kartun Nabi Dari Uni Eropa/Telescoping the Cartoons from European Union." Gatra, March 4, 2006.

Eickelman, Dale F., and John W. Anderson, "Redefining Muslim Publics." In New Media in the Muslim World: The Emerging Public Sphere. Bloomington: Indiana University Press, 2003.

Emon, Anver. "On the Pope, Cartoons, and Apostates." Journal of Law and Religion 22 (2007): 303-21. 
Firestone, Reuven, "Disparity and Resolution in the Quranic Teachings on War: A Reevaluation of a Traditional Problem," Journal of Near Eastern Studies 56, no. 1 (1997): 1-19.

Gadamer, Hans-Georg. Hermeneutik I, Wahrheit Und Methode. Grundzüge Einer Philsophischen Hermeneutik. Tübingen: J. C. B. Mohr., 1986.

Gaither, T. Kenn, and Patricia A. Curtin, "Examining the Heuristic Value of Models of International Public Relations Practices: A Case Study of the Arla Foods Crisis," Journal of Public Relations Research 20 (2008): 115-37. Geipel, John. The Cartoon, A Short History of Graphic Comedy and Satire. London: David \& Charles, 1972.

Goenawan, Mohamad, "Goenawan Mohamad: Reaksi Berlebihan Merepotkan Muslim Eropa/Goenawan Muhamad: Harsh Reaction Leads to Difficult Position of European Muslims." Jaringan Islam Liberal, February 20, 2006. http://islamlib.com/id/artikel/reaksi-berlebihan-merepotkan-muslimeropa/.

Goenawan, Mohamad, "Karikatur," Tempo, February 19, 2006.

Guritno, G. A., and Luqman Hakim, "Arifin Reaksi Keras Ekspresi Bebas/ Harsh Reactions towards Free Expression," Gatra, February 11, 2006.

Hakam, Jamila, "The 'Cartoons Controversy': A Critical Discourse Analysis of English-Language Arab Newspaper Discourse,” Discourse $\mathcal{E}$ Society 20, no. 1 (2009): 33-57.

Hanafî, Hasan. Muqaddima Fî̀ »ilm Al-istighrâb/Introduction to the Science of the West. Bayrût: al-Mu³/4assasah al-Jâmi»îyah lil-Dirâsât wa-al-Tawzî», 1992.

Hansen, Lene, "The Politics of Securitization and the Muhammad Cartoon Crisis: A Post-Structuralist Perspective," Security Dialogue 42, no. 4-5 (2011): 357-67.

Hansen, Lene, "Theorizing the Image for Security Studies," European Journal of International Relations 17, no. 1 (2011): 51-74.

Hasani, Ismail, and Bonar Tigor Naipospos. Dari Radikalisme Menuju Terorisme, Studi Relasi Dan Transformasi Organisasi Islam Radikal Di Jawa Tengah Dan DI Yogyakarta. Jakarta: Pustaka Media, 2012.

Hassner, Ron E., "Blasphemy and Violence," ISQU International Studies Quarterly 55, no. 1 (2011): 23-45.

Hasyim, Syafiq, "Multikulturalisme Baru Barat-Islam/A New Multiculturalism (for) West and Islam," Kompas, February 10, 2006.

Hawting, Gerald R., "Al-Hudaybiyya and the Conquest of Mecca," Jerusalem Studies in Arabic and Islam 8 (1986): 1-23. 
Hefner, Robert W., "Civic Pluralism Denied? The New Media and Jihadi Violence in Indonesia," in New Media in the Muslim World: The Emerging Public Sphere, edited by Dale F. Eickelman and John W. Anderson. Bloomington: Indiana University Press, 2003.

Hidayah, Aguslia, Titis Setianingtyas, and Yanto Musthofa, "Muhammadiyah and NU Protest About Prophet Cartoon Contest." Tempo Interactive, October 9, 2009. http://www.tempointeractive.com/hg/nasional/ 2006/10/09/brk,20061009-85661,uk.html.

Husaini, Adian. "Mengapa Mereka Melecehkan Nabi Muhammad saw/Why Do They Insult the Prophet Muh\}ammad (piece and Blessing Be upon Him)?," February 11, 2006. http://www.adianhusaini.com/index.php? option $=$ com_content $\&$ view $=$ article $\&$ id $=66$ : men gapa-merekamelecehkan-nabi-Muh\}ammad-saw\&catid $=34$ : cap\& Itemid $=53$.

Hussain, A. J., "The Media's Role in a Clash of Misconceptions: The Case of the Danish Muhammad Cartoons," The Harvard International Journal of Press/Politics 12, no. 4 (2007): 112-30.

Ibn Hishām. Al-Sira Al-Nabawiyya, Ed. Musțafă Al-Saqāa, Ibrāhīm Al-Abyā̄ìi, and 'Abd Al-Hāáfiz Salbi. Edited by Mustafá al-Saqā, Ibrāhìm al-Abyārī, and 'Abd al-Ḥāiz Salbì. Cairo: Muștafa al-Bābì wa al-Halibīi, 1375.

Ibn Ish\#aq, and Alfred Guillaume. The Life of Muhammad, A Translation of Is\%âq's Sîrat Rasûl Allâh, with Introd. and Notes by A Guillaume. Karachi: Oxford University Press, 1980.

Ibrahim, Yasmin, "The Mediated 'Ummah' in Europe: The Islamic Audience in the Digital Age," in Media in the Enlarged Europe, Politics, Policy and Industry, edited by Alec Charles, 113-21. Chicago: The University of Chichago Press, 2009.

"Interview with German Islam Expert Bassam Tibi: 'Europeans Have Stopped Defending Their Values.”' Spiegel Online, October 2, 2006, sec. International. http://www.spiegel.de/international/spiegel/interview-withgerman-islam-expert-bassam-tibi-europeans-have-stopped-defending-theirvalues-a-440340.html.

Islamonline.net. "Danish Queen Says Islam Poses Global Threat," April 15, 2005. http://www.islamonline.net/English/News/2005-04/15/ article02.shtml.

Karni, Asrori, S, Luqman Hakim Arifin, and Luky Setyarini, "Maaf Telat Tuan Karikatur Barat/Apology Is Too Late Mr. Western Cartoonists," Gatra, February 11, 2006. 
Keane, David, "Cartoon Violence and Freedom of Expression," Human Rights Quarterly. 304 (2008): 845-75.

Klausen, Jytte, "Rotten Judgment in the State of Denmark," February 8, 2006. http://www.salon.com/opinion/feature/2006/02/08/denmark/ index $1 . h t m l$.

Knight, John G, Bradley S Mitchell, and Hongzhi Gao, "Riding out the Muhammad Cartoons Crisis: Contrasting Strategies and Outcomes," LRP Long Range Planning 42, no. 1 (2009): 6-22.

Laegaard, Sune, "Normative Interpreations of Diversity: The Muhammad Cartoons Controversy and the Importance of Context," Ethnicities 9, no. 3 (2009): 314-33.

Larsson, Georan, "Cyber-Islamophobia? The Case of WikiIslam," Contemporary Islam 1, no. 1 (2007): 53-67.

Lecker, Michael, "The Hudaybiyya Treaty and the Expedition against Khaybar." Jerusalem Studies in Arabic and Islam 5 (1984): 1-11.

Linde-Laursen, Anders, "Is Something Rotten in the State of Denmark? The Muhammad Cartoons and Danish Political Culture," Cont Islam Contemporary Islam/: Dynamics of Muslim Life 1, no. 3 (2007): 265-74.

Lindholm, Kristina, and Eva-Karin Olsson, "Crisis Communication as a Multilevel Game: The Muhammad Cartoons from a Crisis Diplomacy Perspective," The International Journal of Press/Politics 16, no. 2 (2011): 254-71.

Liputan6.com. "MUI: Unjuk Rasa Karikatur Masih Wajar." liputan6.com, February 8, 2006. http://news.liputan6.com/read/117317/mui-unjuk-rasakarikatur-masih-wajar.

Mahmud, Hizbullah, "Muhłammad Dan Hadiah Tahun baru/Muhłammad and the Gift of (Hijra) New Year," February 14, 2006.

Makin, Al, "Benedict XVI and Islam: Indonesian Public Reactions to the Regensburg Address," Islam and Christian-Muslim Relations 20, no. 4 (2009): 409-21.

Makin, Al, "Modern Exegesis on Historical Narratives of the Qur'an, the Case of 'Ad and Thamud according to Sayyid Qutb in His Fi Zilal Al-Qur'an," McGill University, 1999.

Makin, Al, "Pluralism versus Islamic Orthodoxy, the Indonesian Public Debate over the Case of Lia Aminuddin, the Founder of Salamullah Religious Cult," Journal of the International Yale Indonesia Forum Social Justice and Rule of Law: Addressing the growth of a Pluralist Indonesian Democracy (2011). 
March, Andrew F., "Speaking about Muhammad, Speaking for Muslims," Critical Inquiry 37, no. 4 (2011): 806-21.

Müller, Marion G, and Esra Özcan, "The Political Iconography of Muhammad Cartoons: Understanding Cultural Conflict and Political Action," April 2007. http://www.apsanet.org/imgtest/PSApr07Muller_Ozcan.pdf.

Muller, Marion G, Esra Ozcan, and Ognyan Seizov, "Dangerous Depictions: A Visual Case Study of Contemporary Cartoon Controversies," Popular Communication 7, no. 1 (2009): 28-39.

Nalborczyk A.S. "The Perception among Muslim Minorities of Host European Countries: Influence of Legal Status and Citizenship," Global Change Peace Secur. Global Change, Peace and Security 20, no. 1 (2008): 59-69.

NU Online. "Hasyim: Karikatur Nabi Muhammad Menghina Umat Islam/ Hasyim: Muhammad Cartoons Insulted Islamic Community," February 4, 2006. http://www.nu.or.id/page/id/dinamic_detil/1/4091/Warta/ Hasyim__Karikatur_Nabi_Muhammad_Menghina_Umat_Islam.html.

Olesen, Thomas, "The Muhammad Cartoons Conflict and Transnational Activism," Ethnicities 9, no. 3 (2009): 409-26.

Pamuntjak, Laksmi, "Karikatur Dan kemarahan/The Cartoons and the Outrages," Tempo, February 2006.

Peterson, Mark, "Making Global News: 'Freedom of Speech' and 'Muslim Rage' in U.S. Journalism," Contemporary Islam 1, no. 3 (2007): 247-64.

"PKS: Tindak Tegas Pembuat Kartun Nabi/The PKS: Act Sternly against the Cartoonist(s) of the Prophet." Republika, November 20, 2008.

"Polisi Selidiki Pemuatan Kartun Nabi Di internet/The Police Has Investigated the Display of the Cartoon(s) in the Internet." Republika, November 19, 2008.

Ro'uf, Abdul Mukti, "Memahami Kembali Hubungan Islam-Barat/Revisiting the Relation of Islam and the West," Jaringan Islam Liberal, February 20, 2006. http://islamlib.com/id/artikel/memahami-kembali-hubunganislam-barat/.

Rose, Flemming, "Liquid Racism and the Danish Prophet Muhammad Cartoons" Current Sociology 58, no. 5 (2010): 675-92.

Rose, Flemming, "Why I Published Those Cartoons," The Washington Post, February 19, 2006. http://www.washingtonpost.com/wp-dyn/content/ article/2006/02/17/AR2006021702499.html.

Rushton, J. Philippe. Race, Evolution, and Behavior: A Life History Perspective. New Brunswick, N.J., USA: Transaction Publishers, 1995. 
Sambazy, Budiarto, "Antara Barat Dan Asia/Between the West and Asia," Kompas, February 11, 2006.

Saunders, Robert A. "The Ummah as Nation: A Reappraisal in the Wake of the "Cartoons Affair," Nations and Nationalism/ : Journal of the Association for the Study of Ethnicity and Nationalism 14, no. 2 (2008): 3030-3321.

Soage, Ana Belen, "The Danish Caricatures Seen from the Arab World," Totalitarian Movements $\mathcal{E}$ Political Religions 7, no. 3 (2006): 363-69.

Sturges, P., "Limits to Freedom of Expression? Considerations Arising from the Danish Cartoons Affair," IFLA JOURNAL 32, no. 3 (2006): 181-88.

Suryodiningrat, Suryodiningrat, Meidyatama. "Malice or Free Speech in Danish Cartoon?" The Jakarta Post, February 16, 2006.

Suwarjono. "Kartun Nabi Muh\}ammad Di Situs Rakyat Merdeka diprotes/ Cartoon(s) of the Prophet Muh\}ammad in the Website of Rakyat Merdeka Were Protested," February 2, 2006. http://www.detiknews.com/read/ 2006/02/02/160720/531164/10/kartun-nabi-Muh\}ammad-di-situsrakyat-merdeka-diprotes.

Taufik, Ahmad, "Dari Sampul Buku Hingga demonstrasi/From Book Covers to Demonstrations," Tempo, February 19, 2006.

Thoriq, "Mengapa Rasulullah Muhłammad Begitu Dibela umatnya/Why Has the Prophet Muh\}ammad [always] Been Defended by His People[?]," Hidayatullah, February 19, 2006.

Tønder, Lars, "Freedom of Expression in an Age of Cartoon Wars," Theory Contemporary Political Theory 10, no. 2 (2011): 255-72.

Wahyudi, Y. "Arab Responses to Hasan Hanafi's Muqaddima Fi I'lm AlIstighrab.” Muslim World 93 (2003): 233-48.

Wiranto, Rihad, and Nordin Hidayat, "Selamat Tinggal Danish/Goodbye Danish," Gatra, February 11, 2006.

Wright, Thomas. History of Caricature $\mathbb{E}$ Grotesque in Literature and Art: With Illustrations from Various Sources, Drawn and Engraved. London, 1865.

Yudhoyono, Susilo Bambang. "Let's Try to Get beyond Caricatures - The New York Times." New York Time, International Herald Tribune, February 10, 2006. http://www.nytimes.com/2006/02/10/opinion/10ihtedsby.html?_r=0.

Zaman, Muhammad Qasim, "Maghâzî and the Muaddithûn: Reconsidering the Treatment of 'Historical' Materials in Early Collections of Hadith," International Journal of Middle East Studies 28, no. 01 (1996): 1-18. 
